\title{
Elderly health care in the Family Health Strategy and the prevalence of common mental disorders
}

\section{Abstract}

The aims of the present study were to characterize the reasons for medical appointments and treatment procedures of elderly people in the Estratégia Saúde da Família ("Family Health Strategy") (ESF), with emphasis on mental health, as well as to identify the prevalence of common mental disorders, and compare this with the approaches described in medical records. A descriptive and cross-sectional study of 219 elderly persons was performed by reviewing medical records and applying a Self-Response Questionnaire (SRQ-20). For this population the average number of appointments per year was three, $42.3 \%$ of appointments were to obtain a medical prescription, and $70.9 \%$ of medical procedures involved the provision of medical prescriptions. There were eight referrals to specialized mental health services. The most prescribed psychiatric drugs were anxiolytics (55\%), and antidepressants (29.7\%). A total of $19.6 \%$ of the elderly persons had scores above seven in the SRQ-20. It was observed that a large proportion of mental disorders were not detected, and there was a failure in the procedures adopted. More investment in patient flow and the definition of assistance criteria for this population is required.

Venício Aurélio Onofri Júnior Vinícius Spazzapan Martins' Maria José Sanches Marin²
Key words: Primary Health Care; Mental Health; Elderly; Family Health.

\footnotetext{
Faculdade de Medicina de Marília, Curso de Medicina. Marília-SP, Brasil.
}

2 Faculdade de Medicina de Marília, Curso de Enfermagem. Marília-SP, Brasil. 


\section{INTRODUCTION}

Basic healthcare for the elderly is a major concern because of the specific needs of this age group, which are characterized by chronicity and complexity. These needs exert a strong influence on the individuals' quality of life and require appropriate care. Mental health issues also deserve special attention.

The concept of mental health includes mental diseases and emotional problems, both of which can affect an individual's quality of life. In the elderly population, there has been a notable increase in mental health issues, which has been attributed to stressful events, illnesses, disabilities and social isolation. ${ }^{1}$

Elderly individuals with mental disorders are considered to suffer a double burden, which requires special care. ${ }^{2}$ However, despite changes to healthcare models in recent decades and a focus on concepts more closely linked to quality of life and social health production, these initiatives have rarely been converted into practical results.

In addition, social representations of health professionals and the community contribute to mental health problems among the elderly being confused with the natural aging process. This in turn leads to delays in diagnoses and treatment. ${ }^{3}$

In Brazil, public policies such as the Politica Nacional do Idoso (National Policy for the Elderly) (PNI) have been instituted and regulated. In 1996, a policy was created to ensure the social rights of the elderly, creating conditions that would promote their autonomy, as well as their integration and effective participation in society. ${ }^{4}$ The Estatuto do Idoso (the Elderly Statute), which was approved through Law no. 10.741/2003, sets out the priorities for the protection of the rights of the elderly population. ${ }^{5}$

In the Pacto pela Saúde (the Pact for Health) (2006), a dimension known as the Pacto em defesa da vida (Pact in defense of life) established the health of the elderly as one of six priorities. In the same year, Ordinance no. 2528 was revised, establishing the Politica Nacional de Saúde da Pessoa Idosa (National Health Policy for the Elderly) (PNSI), the aim of which was to promote adequate and dignified healthcare for the elderly, as well as to recover, maintain and promote their independence, in line with the principles of the SUS (Sistema Único de Saúde (Unified Health System)). ${ }^{6}$ This ordinance defined that healthcare for the elderly would begin with Primary Healthcare/Family Health. ${ }^{7}$

Thus, considering basic health care as the starting point in the health system and the solution to a great many problems through the use of techniques of lower technological density, as well as the bonds, accountability and continuity of care, it is hoped that the health of the elderly will be monitored and analyzed in its multiple dimensions.

In 1978, a movement of "psychiatric reform" began in an attempt to promote deinstitutionalization and to create a network of community services, such as the Centros de Atenção Psicossocial (Psychosocial Care Centers) (CAPS), the Programa de Volta para Casa (Back to Home Program) and mental health matrix support for primary health care teams. However, in practice, these actions are more strongly associated with treating severe, chronic and incapacitating diseases. Treatment for less serious (and more common) disorders has remained in the background. ${ }^{8}$

Concerning mental health care in the Estratégia Saúde da Familia (Family Health Strategy) (ESF), it is clear that teams are incapable of adequately attending the mental health needs of the population in their territories. This has been attributed to the level of complexity of this type of care, added to the incipiency of public policies, which have led to the emergence of a large gap between the real service and that which was previously proposed. ${ }^{9}$

Ordinance no. 154/MS (2008) created the Núcleos de Apoio à Saúde da Familia (Family Health Support Nucleus) (NASFs), which provide matrix support and involve mental health professionals. ${ }^{10}$ However, in certain municipalities, these NASF teams do not include psychiatrists, due to the low 
availability of these professionals and the failure to prioritize their presence on the teams.

Based on the requirements of health service organizations that were established in 2010, the Ministry of Health released guidelines for the Organização das Redes de Atenção a Saúde (Organization of Healthcare Networks) (RAS) in order to ensure the activity and services of these networks are provided effectively and efficiently. Within these guidelines, primary health care was attributed the responsibility to solve most of the health problems of the population, including the organization of flow and counterflow and looking after patients at different stages of the healthcare service. The psychosocial care network was defined as a priority, with an emphasis on controlling the abuse of alcohol and illicit drugs. ${ }^{11}$

As a result of the increasing elderly population, the high prevalence of mental illness in this segment of the population and the incipiency of public policies, there is a need for new ideas and proposals related to health interventions for elderly individuals in the ESF, particularly in relation to mental health, in order to improve their quality of life. The present study was based on the following questions: what are the reasons and complaints that force the elderly to seek assistance in the ESF? What is the prevalence of mental disorders among the elderly and are they correlated with medical practices? Therefore, the aim of the present study was to characterize the reasons why elderly individuals make medical appointments and the strategies adopted, with an emphasis on mental health, as well as to identify the prevalence of mental disorders and compare the approaches described in medical records.

\section{METHODS}

This quantitative, cross-sectional, descriptive, exploratory study was conducted in the Unidades de Saúde da Família (Family Health Units) (USF) of a medium-sized municipality in the state of São Paulo (approximate population of 218,000 inhabitants). Primary health care was gradually implemented in the ESF, which currently operates 32 Units and serves almost $50 \%$ of the population. These units are supported by two multi-professional teams from the Núcleo de Apoio à Saúde da Familia (Family Health Support Nucleus) (NASF). Concerning the specialized services, particularly in relation to mental health, the municipality uses CAPS II: outpatient psychiatric care that is conducted in a specialized care unit (Polyclinic); and psychiatric care services in four Basic Health Units.

The mental health care network is also composed of a Regional Mental Health Ward, which offers the following services: specialized medical care; psychotherapy; occupational therapy; social assistance support; a unit (18 beds) for psychiatric hospitalization in a general hospital; CAPS AD, for the treatment of chemical dependents; a psychiatric hospital linked with the SUS, which treats adults (above 18 years) for severe mental disorders and chemical dependence; and a day-hospital (30 places) for the treatment of adult patients. ${ }^{12}$

Of the 218,000 inhabitants, 27,800 are elderly (60 years or more), which represents $12.7 \%$ of the total population. The sample used in the present study contained 219 elderly individuals. The expected prevalence of mental disorders was $30 \%{ }^{13}$ and the expected detection rate of these cases by professionals working in the health units was $50 \%{ }^{14}(p=15 \%)$. The confidence interval was set at $95 \%$.

Data was collected from six USFs, which represents approximately $20 \%$ of all units in the municipality. The units were selected at random (draw) and then identified using the letters A, B, C, D, E and F, with an elderly population of 444, 514, 361, 172, 264 and 218, respectively. The sample was proportional to the size of the elderly population in each of the USFs selected. In total, 49 medical records were analyzed from USF A, with a further 57 from unit $\mathrm{B}, 39$ from unit $\mathrm{C}, 19$ from unit D, 29 from unit $\mathrm{E}$ and 26 from unit $\mathrm{F}$, also based on a draw, which used a list of elderly patients provided by Agentes Comunitários de Saúde (Community Health Agents) (ACS). 
The data was collected in two stages between August and December of 2012. In the first stage, the data was gathered from the medical records of the elderly patients selected $(n=219)$. To do this, a script that had been elaborated by the researcher was used. This script contained identification data, the reasons for medical appointments, which were classified according to the Classificação Estatística Internacional de Doenças e Problemas Relacionados com a Saúde (International Statistical Classification of Diseases and Related Health Problems), (ICD 10), as well as the medical strategies used in the appointments during a period of one year. In the second stage, the homes of the 219 elderly individuals to be analyzed were visited in order to apply the Self Response Questionnaire (SRQ) and determine the prevalence of mental disorders. In the present study, the SRQ-20 version was used, which contains 20 questions that seek to identify mild mental disorders, excluding psychotic problems, as well as disorders related to seizures and alcohol consumption. The SRQ-20 questionnaire is divided into four groups of symptoms ${ }^{15}$ : a depressiveanxious mood, which corresponds to items 6,4 , 9 and 10; somatic symptoms (items 1, 2, 3, 5, 7 and 20); a decrease in vital energy (items $8,11,12$, 13, 18 and 19); and depressive thoughts (items 14, 15, 16 and 17), in accordance with the respective frequency of the response. The reference value, or "passing score", used in the present study, as in most studies that used the same instrument, was eight points or more, which identified those at risk of common mental disorders..$^{15}$

During the home visits, those who had been referred for some form of specialized mental healthcare were questioned about the course of this treatment and the strategy adopted.

The second stage involved 183 elderly individuals, who completed the SRQ-20. Fourteen individuals $(6.4 \%)$ refused to participate, 16 (7.3\%) were not found in their homes and six $(2.7 \%)$ were considered incapable of providing the data required due to cognitive impairment.

The data obtained was entered into an Excel spreadsheet (Microsoft Office Excel 2010) and then analyzed using version 7.0 of Statistica software. The chi-squared test was applied to determine the correlation between the total scores in the SRQ20 and the prescription of psychiatric medication. The level of significance was set at 0.05 . In order to determine if there was a greater prevalence in one of the four groups of symptoms among the SRQ-20 responses, the partial scores of the questionnaire were compared separately for gender using ANOVA and the Friedman test. The SRQ-20 partial scores were adopted as dependent variables for the following: somatic symptoms; a depressiveanxious mood; depressive thoughts and a decrease in vital energy.

The present study was authorized by the Municipal Health Secretariat and the Conselho Municipal de Avaliaşão em Pesquisa (Municipal Council for Research Assessment) (COMAP) under protocol number 179/12-SS. It was also approved by the Human Research Ethics Committee of the Faculdade de Medicina de Marilia under protocol number 691/12. The elderly individuals that participated in the second stage of the present study signed a Free and Informed Consent Form (FICF).

\section{RESULTS}

In total, 219 Family Health Unit patient records were assessed. Of this total, 141(64.4\%) were female. The predominant age group was between 60 and 69 years, with 105 patients $(47.9 \%)$, whereas only $39(17.8 \%)$ of the participants were aged 80 years or more. Table 1 displays the totals per unit and the total number of appointments. 
Table 1. Distribution of the 219 elderly individuals according to the health unit and the number of medical appointments in one year. Marília, SP, 2013.

\begin{tabular}{|c|c|c|c|c|c|c|c|c|c|c|c|c|c|c|}
\hline \multirow[t]{2}{*}{$\begin{array}{c}\mathrm{N}^{\mathrm{o}} \text {. of } \\
\text { appointments }\end{array}$} & \multicolumn{2}{|c|}{ A } & \multicolumn{2}{|c|}{ B } & \multicolumn{2}{|c|}{$\mathrm{C}$} & \multicolumn{2}{|c|}{$\mathrm{D}$} & \multicolumn{2}{|c|}{$\mathrm{E}$} & \multicolumn{2}{|c|}{$\mathrm{F}$} & \multicolumn{2}{|c|}{ Total (\%) } \\
\hline & $\mathrm{n}$ & $\%$ & $\mathrm{n}$ & $\%$ & $\mathrm{n}$ & $\%$ & $\mathrm{n}$ & $\%$ & $\mathrm{n}$ & $\%$ & $\mathrm{n}$ & $\%$ & $\mathrm{n}$ & $\%$ \\
\hline 0 & 12 & 24.4 & 8 & 14.8 & 18 & 46.1 & 3 & 15.7 & 6 & 20.6 & 12 & 46.1 & 59 & 27.0 \\
\hline 1 to 5 & 27 & 55.1 & 35 & 61.4 & 20 & 51.3 & 7 & 36.8 & 14 & 48.3 & 12 & 46.1 & 115 & 52.5 \\
\hline 6 to 10 & 8 & 16.3 & 11 & 19.3 & 1 & 2.6 & 6 & 31.6 & 6 & 20.7 & 1 & 3.8 & 33 & 15.0 \\
\hline 11 or + & 2 & 4.0 & 3 & 5.2 & 0 & 0 & 3 & 15.8 & 3 & 10.4 & 0 & 0 & 8 & 3.5 \\
\hline Total & 49 & 22.3 & 57 & 26.0 & 39 & 17.8 & 19 & 8.6 & 29 & 13.2 & 26 & 11.9 & 219 & 100.0 \\
\hline
\end{tabular}

The 219 elderly patients had a total of 661 appointments in the year-long period, which resulted in a mean of three appointments/elderly individual/year. However, 59 (27.3\%) did not have a single appointment in their ESF. In units $\mathrm{C}$ and F, this proportion was 18 (46.1\%) and 12 (46.1\%), respectively. The mean number of appointments per unit ranged from 0.97 per patient in unit $\mathrm{C}$ to 5.73 per patient in unit $\mathrm{D}$ (Table 1 ).

In total, 981 reasons for attending were stipulated in the records of the 661 appointments: $415(42.3 \%)$ patients wanted to obtain a prescription;
$337(34.5 \%)$ cited complaints (signs and symptoms) related to different body systems; and 72 (7.3\%) attended to receive the results of an examination (Table 2).

Table 3 displays the 337 complaints (signs and symptoms) cited by the participants. The most common symptoms were related to the following: the osteomuscular system and connective tissue (82 patients, $24.0 \%$ ); the digestive and respiratory systems (both with 39 patients, 11.5\%); signs and symptoms of mental and behavioral disorders (33 patients, $10.0 \%)$.

Table 2. Distribution of the reasons given for medical appointments among the 219 elderly individuals during the year. Marília, SP, 2013.

\begin{tabular}{lcc}
\hline \multicolumn{1}{c}{ Reasons } & $\mathrm{n}$ & $\%$ \\
\hline To get a prescription & 415 & 42.3 \\
Complaints (signs/symptoms) & 337 & 34.5 \\
Routine appointment & 131 & 13.3 \\
Result of examinations & 72 & 7.3 \\
Others & 26 & 2.6 \\
Total & 981 & 100.0 \\
\hline
\end{tabular}


Table 3. Distribution of the number of signs and symptoms exhibited by the 219 elderly individuals during one year of medical appointments, classified by bodily systems/ apparatus. Marília, SP, 2013.

\begin{tabular}{lcc}
\hline \multicolumn{1}{c}{ Complaint (symptom) } & $\begin{array}{c}\mathrm{N}^{\mathrm{o}} \text {. of } \\
\text { Occurrences }\end{array}$ & $\%$ \\
\hline Osteomuscular system and connective tissue & 82 & 24.0 \\
Digestive system & 39 & 11.5 \\
Respiratory system & 39 & 11.5 \\
Mental and behavioral disorders & 34 & 10.0 \\
Genitourinary system & 29 & 8.6 \\
Nervous system & 17 & 5.0 \\
Circulatory system & 12 & 3.5 \\
Skin and subcutaneous tissue & 10 & 2.9 \\
Ear and mastoid apophysis & 8 & 2.3 \\
Lesions & 6 & 1.8 \\
Eyes and annexes & 4 & 1.1 \\
Endocrine. nutritional and metabolic illnesses & 3 & 0.9 \\
Other complaints & 55 & 16.3 \\
Total & 337 & 100.0 \\
\hline
\end{tabular}

As a result of the 661 medical appointments, 1385 prescriptions were written. Of these, 982 $(70.9 \%)$ were prescriptions for medication, while $293(21.2 \%)$ solicited complementary examinations and $110(7.9 \%)$ referred the patient to another health service. Of the drugs prescribed, 280 $(28.5 \%)$ were for mental and behavioral disorders. Concerning the referrals, the majority were sent to emergency care services, whereas eight $(7.3 \%)$ were referred to specialized mental health services.

Table 4 displays the drugs prescribed for mental and behavioral disorders according to their class: anxiolytics, which represented $55 \%$ of all prescriptions; anti-depressants (29.7\%); antipsychotics (6.4\%); mood stabilizers (7.8\%); antiparkinsonian and anticonvulsant drugs (both with $1.5 \%$ ). The most commonly prescribed drugs were diazepam (20.0\%), clonazepam (19.6\%), amitriptyline (15.0\%) and fluoxetine (7.9\%).

The SRQ-20 questionnaire was applied to 183 elderly individuals, of whom 115 (62.8\%) were female. In total, 36 (19.6\%) individuals scored more than seven points.

In the present sample, the highest mean value of affirmative responses was found for depressiveanxious mood (35.24\%), followed by a decrease in vital energy (23.4\%), somatic symptoms (19.66\%) and depressive thoughts (15.56\%) (Table 5). 
Table 4. Distribution of the medications prescribed for mental and behavioral disorders among 219 elderly individuals, according to the drug class. Marília, SP, 2013.

\begin{tabular}{|c|c|c|}
\hline Medication & $\mathrm{n}$ & $\%$ \\
\hline Anxiolytics & 154 & 55.0 \\
\hline Diazepam & 56 & 20.0 \\
\hline Clonazepam & 55 & 19.6 \\
\hline Bromazepam & 22 & 7.9 \\
\hline Alprazolam & 9 & 3.2 \\
\hline Nitrazepam & 7 & 2.5 \\
\hline Flunitrazepam & 5 & 1.8 \\
\hline Antidepressants & 78 & 29.7 \\
\hline Amitriptyline & 42 & 15.0 \\
\hline Fluoxetine & 22 & 7.9 \\
\hline Limbitrol(Amitrip/Chlordiazepoxide) & 5 & 1.8 \\
\hline Imipramine & 3 & 1.1 \\
\hline Citalopram & 2 & 0.7 \\
\hline Venlafaxine & 2 & 0.7 \\
\hline Mirtazapine & 1 & 0.4 \\
\hline Sertraline & 1 & 0.4 \\
\hline Antipsychotics & 18 & 6.4 \\
\hline Chlorpromazine & 8 & 2.9 \\
\hline Sulpiride & 7 & 2.5 \\
\hline Risperidone & 2 & 0.7 \\
\hline Haloperidol & 1 & 0.4 \\
\hline Mood stabilizers & 22 & 7.8 \\
\hline Carbamazepine & 17 & 6.0 \\
\hline Lithium Carbonate & 5 & 1.8 \\
\hline Antiparkinsonian & 4 & 1.5 \\
\hline Anticonvulsant & 4 & 1.5 \\
\hline
\end{tabular}


Table 5. Distribution of responses to the SRQ-20 questionnaire, applied to 183 elderly individuals. Marília, SP, 2013.

\begin{tabular}{|c|c|c|c|c|}
\hline & \multicolumn{2}{|c|}{ No } & \multicolumn{2}{|c|}{ Yes } \\
\hline & $\mathrm{n}$ & $\%$ & $\mathrm{n}$ & $\%$ \\
\hline \multicolumn{5}{|l|}{ Somatic symptoms } \\
\hline 1. Do you have frequent headaches? & 156 & 85.30 & 27 & 14.70 \\
\hline 2. Do you have a lack of appetite? & 147 & 80.33 & 36 & 19.67 \\
\hline 3. Do you sleep badly? & 131 & 71.59 & 52 & 28.41 \\
\hline 5. Do your hands shake? & 154 & 84.16 & 29 & 15.84 \\
\hline 7. Do you have indigestion? & 147 & 80.33 & 36 & 19.67 \\
\hline 20. Do you have stomach pains? & 147 & 80.33 & 36 & 19.67 \\
\hline \multicolumn{5}{|c|}{ Depressive-anxious mood } \\
\hline 4. Are you easily frightened? & 132 & 72.14 & 51 & 27.86 \\
\hline 6. Do you feel nervous, tense or preoccupied? & 86 & 47.00 & 97 & 53.00 \\
\hline 9. Have you felt sad recently? & 114 & 62.30 & 69 & 37.70 \\
\hline 10. Have you cried more than normal recently? & 142 & 77.60 & 41 & 22.40 \\
\hline \multicolumn{5}{|l|}{ Depressive thoughts } \\
\hline 14. Are you incapable of performing a useful role in your life? & 160 & 87.44 & 23 & 12.56 \\
\hline 15. Have you lost interest in things? & 130 & 71.59 & 52 & 28.41 \\
\hline 16. Do you feel like a useless person, with no value? & 151 & 82.54 & 32 & 17.46 \\
\hline 17. Have you thought about ending your life? & 157 & 96.18 & 7 & 3.82 \\
\hline \multicolumn{5}{|l|}{ Decrease in vital energy } \\
\hline 8. Do you have difficulty thinking clearly? & 156 & 85.25 & 27 & 14.75 \\
\hline $\begin{array}{l}\text { 11. Have you experienced difficulties when trying to perform } \\
\text { your daily activities to a satisfactory level? }\end{array}$ & 160 & 87.44 & 23 & 12.56 \\
\hline 12. Have you had difficulty making decisions? & 122 & 66.67 & 61 & 33.33 \\
\hline $\begin{array}{l}\text { 13. Have you had problems in your job? (Is it laborious? Does it } \\
\text { make you suffer?) }\end{array}$ & 153 & 83.61 & 30 & 16.39 \\
\hline 18. Do you feel tired all the time? & 144 & 78.69 & 39 & 21.31 \\
\hline 19. Do you tire easily? & 106 & 57.93 & 77 & 42.07 \\
\hline
\end{tabular}

Of the 183 elderly individuals who completed the SRQ-20, 132 (72.1\%) had not received any prescription for antipsychotic drugs in the period, whereas $12(6.6 \%)$ were only medicated with psychiatric drugs and $39(21.3 \%)$ used a mixture of psychiatric drugs and drugs from other classes.
Based on the non-medicated and medicated (psychiatric drugs) groups, no correlation was found between the total scores in the SRQ-20 and the prescription of psychotropic drugs (Table 6). 
Table 6. Correlation between the SRQ-20 score and the prescription of psychiatric medication. Marília, SP, 2013.

\begin{tabular}{lccc}
\hline & SRQ-20 $>7$ & SRQ-20 $\leq 7$ & Total (\%) \\
\hline Received a prescription & 9 & 42 & $51(27.9)$ \\
No prescription & 27 & 105 & $132(72.1)$ \\
Total & $36(19.6 \%)$ & $147(80.4 \%)$ & $183(100.0)$ \\
\hline
\end{tabular}

Concerning the elderly individuals who were sent for specialized mental health care, four $(50.0 \%)$ had been treated and the rest were still waiting to be seen. No counter-references were recorded and the treatment provided was mainly medication-based.

\section{DISCUSSION}

The majority of the elderly participants in the present study were female, which is in line with the demographic profile of Brazil. This is due to high rates of mortality related to violence, traffic accidents and chronic diseases among men. Women are more likely to heed the signs and symptoms of health issues, and to seek assistance, than men. ${ }^{16}$

Concerning age groups, there was a notably high proportion of individuals aged 80 years or more, which highlights the increase of this age group, who tend to experience more health problems and limitations. ${ }^{17,18}$

Concerning the number of consultations, data from DATASUS confirmed that in the state of São Paulo for the year 2010, a mean of 3.4 medical appointments/inhabitant/year were conducted through the SUS. This mean value includes primary health care appointments, consultations with specialists, urgent cases and emergencies, as well as appointments involving children and pregnant women. ${ }^{19}$

A study in a Brazilian state capital assessed 13,701 participants aged 20 years or more and indicated that the use of health services increases with age. In total, $53.9 \%$ of those aged 60 years or more had three or more appointments, whereas $11.3 \%$ did not see a doctor during the same period. ${ }^{20}$

When analyzing the high proportion of elderly individuals who had not had a medical appointment in a basic health unit for 12 months, as well as the differences in the mean number of appointments in each unit, these individuals are falling short of the minimum standards that have been established for health care. This also highlights the lack of attention given to health care for the elderly in the USFs in the municipality, given that it seems to be the responsibility of each unit to coordinate flow and define their service priorities.

A study of the use of health care services on behalf of the elderly was conducted in the state of Paraná, confirming that $50.1 \%$ of the elderly participants had not had a medical appointment in the three months prior to the interviews. However, $11.7 \%$ had made use of some form of urgent or emergency service in the municipality. The authors attributed this occurrence to the risks found in the elderly population or a possible lack of resoluteness in the activity of the UBSs. ${ }^{21}$

However, studies ${ }^{20,21}$ of the frequency of medical appointments per elderly individual are not limited to primary health care, which probably contributed to the greater proportion of medical appointments found per patient, when compared with the present study. However, by establishing the role of primary health care as the starting point for the health system, given its bond and continuity, it can be inferred that health care for the elderly still requires improvements. Due to the chronicity of the problems the elderly face, they require systematic monitoring. In general, the 
organization of primary health care is unfavorable for the inclusion of elderly patients, particularly in terms of the doctor/patient relationship, due to the high turnover of doctors, inadequate physical structures and the delays involved in scheduling appointments. ${ }^{22}$ Some of these problems were also encountered in the municipality assessed in the present study.

There is a correlation between the lack of systematic service for the elderly in primary health care and the fact that very few medical appointments are characterized as routine. This suggests a care service that is focused on demand, with little emphasis on monitoring common chronic conditions among the elderly. This segment of the population requires control and support, particularly concerning the prevention of complications and the improvement of function and quality of life. Mental problems could be easily detected and controlled in a differentiated health care system.

It is notable that almost half of the reasons given for medical appointments involved the attainment of a prescription for medicine, according to the records analyzed. It is possible that the lack of a more detailed description of the service contributed to this reasoning. However, one cannot simply disregard the fact that this is essentially correlated to the medicalization of the health system, with little emphasis on lifestyle changes. This should be a concern for professionals in primary health care and can be improved through constant reinforcements and agreements, which are favored by the bond created between ESF professionals and patients.

Many of the reasons provided for appointments were due to some form of complaint. Of these, $33(10 \%)$ were related to mental and behavioral disorders. However, there was a predominance of pain complaints, particularly for the osteomuscular system and the connective tissue. These complaints were often isolated and were not explained by any diagnostic hypothesis based on clinical reasoning, which could indicate the presence of somatic symptoms. Among the most common mental disorders, somatic symptoms are extremely common and thus, pain complaints are quite frequent. It is not possible to state the proportion of these complaints that could be identified as a "somatization" (physical symptoms associated with emotional issues). This would lead to an increase in the quantity of complaints related to common mental disorders (depressive, anxious, somatoform and dissociative symptoms), without necessarily fulfilling all of the diagnostic criteria for a disorder or a mental disorder episode, according to the ICD 10.

Furthermore, the analysis of the drugs prescribed for these problems indicated that there was a notably high quantity of psychiatric medication. This quantity was even higher than that of analgesics, although no correlation was found between the presence of pain and the use of psychotropic drugs.

Concerning the prescription of benzodiazepines, there was a greater number of prescriptions for diazepam and clonazepam, which have a long halflife and promote sedation, cognitive impairment and the development of chemical dependance. ${ }^{23}$ In general, benzodiazepines should be avoided. The prescription of drugs with a shorter half-life (and no metabolites) is considered a safer option. ${ }^{24}$

Concerning antidepressants, two substances made up $80 \%$ of all prescriptions: amitriptyline and fluoxetine. The use of antidepressants should be indicated when there is a diagnosis of depression or anxiety. It should also be restricted to serotonin reuptake inhibitors. Amitriptyline is a tricyclic antidepressant with sedative properties and is contraindicated for elderly individuals, due to a long list of side-effects. ${ }^{24,25}$

The most commonly recommended treatment for mood disorders and anxiety among elderly individuals are selective serotonin reuptake inhibitors (SSRIs), such as fluoxetine, citalopram and sertraline. The most commonly prescribed SSRI in the present study was fluoxetine, followed 
by citalopram and sertraline. Since the three drugs are distributed by the public network, it is clear that they are given priority when prescribing antidepressants for the elderly. ${ }^{24}$

The other classes of psychotropic drugs were prescribed less frequently than the abovementioned substances. Nevertheless, it is important to consider the side-effects of antipsychotic drugs, including extrapyramidal symptoms (muscle rigidity, difficulty walking, dyskinesias), which can increase the risk of falls. Thus, they should be prescribed in the lowest possible doses. ${ }^{24,25}$

Earlier studies have reported higher SRQ-20 values than those reported herein. In a municipality in the Northeast of Brazil, the SRQ was used with a passing score and a prevalence of $32.17 \%$ was recorded, with the worst results correlated with advancing age and low income. ${ }^{26}$ Of the 1432 elderly individuals (mean age of 69.9 years) assessed in the city of Campinas in the state of São Paulo, 29.7\% recorded scores above seven. Positive correlations were found for gender (female), age (above 80 years), low income, a higher number of illnesses and an unfavorable health self-assessment. Concerning the groups of signs and symptoms, a depressive-anxious mood was the most common, which is similar to the result found in the present study and in literature. ${ }^{27,28}$

The absence of a correlation between patients with a SRQ-20 score over seven and the prescription of psychotropic drugs indicates a lack of recognition of clinical situations that could require attention in primary health care. Conversely, a number of elderly individuals were not identified as patients with psychiatric symptoms in the questionnaire despite using medication. This demonstrates the chronic use of drugs, which needs to be revised in order to achieve clinical improvements through treatment.

A more detailed analysis of the mental health aspects addressed in the SRQ-20 confirmed that items referring to a depressive-anxious mood were the most common. Considering that these items include the questions "are you easily frightened", "do you feel nervous, tense or preoccupied", "have you felt sad recently" and "have you cried more than normal recently", it would appear that this segment of the population lives in silent suffering.

In addition, the presence of depressive symptoms is a risk factor for the development of dependence when performing activities of daily living. Subsyndromal patients and those with less depression became more depressed that the nondepressive group. ${ }^{29}$ Therefore, the importance of detecting these signs and symptoms is paramount in order to institute early interventions related to modifiable risk factors such as social support and psychological functioning. ${ }^{29,30}$

In the present study, only eight of the participants had been sent for mental health assessments and of these, four were still waiting to be seen. This low number, which is correlated with the high amount of prescriptions for psychiatric medication, indicates that many patients with mental symptoms or disorders are minimally assisted and medicated in the units themselves.

Although it was possible to obtain data concerning the health of the elderly in basic care units and confirm correlations with the presence of common mental disorders, the present study contains a number of limitations. The results are only based on a period of one year and the information that was available in the relevant medical records. Thus, it is possible that some of the individuals in the sample had been treated for mental health issues by other professionals. It is also possible that some form of intervention had occurred prior to the period analyzed.

\section{FINAL CONSIDERATIONS}

The data presented herein reiterates that health care for the elderly in the ESF essentially deals with complaints and prescribes drugs. As a result, the focus is on biological aspects. Although the elderly participants exhibited complaints and used 
medication for mental and behavioral disorders, no significant correlation was found for the presence of mental disorders. It seems that the mental health of the elderly is essentially treated through the Estratégia Saúde da Familia (Family Health Strategy), given that there are few indications that these patients seek care elsewhere. The concern is that these problems may not be detected and when

\section{REFERENCES}

1. Borim FSA, Barros MBA, Botega NJ. Transtorno mental comum na população idosa: pesquisa de base populacional no Município de Campinas, São Paulo, Brasil. Cad Saúde Pública [ Internet] 2013 [acesso em 24 jun. 2013];29(7):1415-26. Disponível em: http://www.scielo.br/scielo.php?script $=$ sci_ arttext\&pid=S0102-

2. Graham N, Lindesay J, Katona C, Bertolote J M, Camus V, Copeland JRM, et al. Redução da estigmatização e da discriminação das pessoas idosas com transtornos mentais: uma declaração técnica de consenso. Rev Psiquiatr Clín (São Paulo) 2007;34(1):39-49.

3. Tanaka OY, Ribeiro EL. Ações de saúde mental na atenção básica: caminho para ampliação da integralidade da atenção. Ciênc Saúde Coletiva 2009;14(2):477-86.

4. Keinert TMM, Rosa TEC. Direitos humanos, envelhecimento ativo e saúde da pessoa idosa: marco legal e institucional. BIS, Bol Inst Saúde. 2009;(47):4-8.

5. Brasil. Lei federal $\mathrm{n}^{\mathrm{o}}$ 10.741, de 01 de outubro de 2003. Dispõe sobre o Estatuto do Idoso e dá Providências. Brasília, DF, Diário Oficial da União. 3 out. 2003.

6. Brasil. Ministério da Saúde. Portaria n. ${ }^{\circ} 399$, de 22 de fevereiro de 2006. Divulga o Pacto pela Saúde 2006. Consolidação do SUS e aprova as diretrizes operacionais do referido pacto. Diário Oficial da União, Brasília, DF. 23 fev. 2006. Seção 1:43.

7. Louvison MCP, Barros S. Políticas públicas e envelhecimento: a construção de uma política de direitos e os desafios da atenção integral à saúde da pessoa idosa no SUS. BIS, Bol Inst Saúde 2009;(47):9-15. they are, therapeutic measures based on the best scientific evidence are not always followed. Thus, primary health care requires further investment for service flow and the definition of service criteria for this segment of the population, with a view to promoting equal access, professional training and a modality of care that defines and guides the path of the elderly at all levels of health care.

8. Brasil. Ministério da Saúde,Secretaria de Atenção à Saúde. DAPE. Coordenação Geral de Saúde Mental. Reforma psiquiátrica e política de saúde mental no Brasil. Documento apresentado à Conferência Regional de Reforma dos Serviços de Saúde Mental: 15 anos depois de Caracas. OPAS. Brasília, DF: OPAS; 2005.

9. Onocko-Campos RT, Campos GWS, Ferrer AL, Corrêa CRS, Madureira PR, Gama CAP, et al. Avaliação de estratégias inovadoras na organização da Atenção Primária à Saúde. Rev Saúde Pública 2012;46(1):43-50.

10. Brasil. Ministério da Saúde, Secretaria de Atenção à Saúde, Departamento de Atenção Básica. Diretrizes do NASF: Núcleo de Apoio a Saúde da Família. Brasília, DF: Ministério da Saúde; 2010 [acesso 24 jun. 2013]. 152 p. (Série A. Normas e Manuais Técnicos) (Caderno de Atenção Básica, n. 27). Disponível em: http://bvsms.saude.gov.br/bvs/publicacoes/ diretrizes_do_nasf_nucleo.pdf

11. Brasil. Ministério da Saúde. Portaria n. ${ }^{\circ} 4.279$ de 30 de dezembro de 2010. Estabelece diretrizes para organização da rede de atenção à saúde do SUS. Saúde Legis. 2010. Disponível em: http://bvsms.saude. gov.br/bvs/saudelegis/gm/2010/anexos/anexos_ prt4279_30_12_2010.pdf

12. Marília. Secretaria Municipal de Saúde de Marília. Programa Municipal de Saúde Mental. Marília: Prefeitura Municipal de Marília; 2010.

13. Vasconcelos-Rocha S, Almeida MMG, Araújo TM, Medeiros-Rodrigues WK, Barreto-Santos L, VirtuosoJúnior J. Prevalência de transtornos mentais comuns em idosos residentes em município no nordeste do Brasil. Rev Salud Pública 2012;14(4):620-29. 
14. Ávila-Funes JA, Melano-Carranza E, Payette H, Amieva H. Síntomas depresivos como factor de riesgo de dependencia en adultos mayores. Salud Pública Méx 2007;49(5):367-75.

15. Santos KOB, Araujo TM, Oliveira NF. Estrutura fatorial e consistência internado Self Response Questionnaire (SRQ 20) em uma população urbana. Cad Saúde Pública 2009;25(1):214-22.

16. Fundação Sistema Estadual de Análise de Dados [Internet]. São Paulo: Fundação SEADE; 2013 [acesso em 10 out. 2013]. Disponível em:http://www.seade. gov.br/produtos/perfil_estado/index.php

17. Eliopoulos C. Enfermagem Gerontológica. $7^{\mathrm{a}} \mathrm{ed}$. Porto Alegre: Artmed; 2011. Cap 1, A população que envelhece; p. 29-38.

18. Zanchettin SP, Marin MJS, Rodrigues MR. Living and health conditionsof elderly people over 80 . Rev Gaúcha Enferm 2015;36(3):42-8.

19. DATASUS. Sistema de informações ambulatoriais do SUS [Internet]. Brasília ,DF: Ministério da Saúde; 2011 [acesso em 10 out. 2013]. Disponível em: http:// tabnet.datasus.gov.br/cgi/tabcgi.exe?idb2011/f01.def

20. Lima-Costa MF, Loyola Filho AI, Matos DL. Tendências nas condições de saúde e uso de serviços de saúde entre idosos brasileiros: um estudo baseado na Pesquisa Nacional por Amostra de Domicílios (1998, 2003). Cad Saúde Pública 2007;23(10):2467-78.

21. Pilger C, Menon M U, Mathias TAF. Utilização de serviços de saúde por idosos vivendo na comunidade. Rev Esc Enferm USP 2013;47(1):213-20.

22. Vianna LG, Vianna C, Bezerra AJC. Relação médicopaciente idoso: desafios e perspectivas. Rev Bras Educ Med 2010;34(1):150-9.
23. Schatzberg AF, Cole JO, Debattista C. Manual de psicofarmacologia clínica. $\sigma^{a}$ ed. Porto Alegre: Artmed; 2009.

24. Holt S, Schmiedl S, Thürmann PA. Potentially inappropriate medications in the elderly: the PRISCUS list. Dtsch Arztebl Int 2010;107(3132):543-51.

25. Cassoni TCJ, Corona LP, Romano-Lieber NS, Secoli SR, Duarte YAO, Lebrão ML. Uso de medicamentos potencialmente inapropriados por idosos do Município de São Paulo, Brasil: Estudo SABE. Cad Saúde Pública 2014;308:1708-20.

26. Vasconcelos-Rocha S, Almeida MMG, Araújo TM, Medeiros-Rodrigues WK, Barreto-Santos L, Virtuoso-Júnior JS. Prevalencia de desórdenes mentales comunes en individuos de tercera edad, residentes en un municipio del Noreste de Brasil. Rev Salud Pública 2012;14 (4):620-29.

27. Oliveira DAAP, Gomes L, Oliveira RF. Prevalência de depressão em idosos que frequentam centros de convivência. Rev Saúde Pública 2006;40(4):734-6.

28. Snowdon J. How high is the prevalence of depression in old age? Rev Bras Psiquiatr 2002;24 Suppl 1:42-7.

29. Lyness JM, Yu Q, Tang W, Tu X, Conwell Y. Risks for depression onset in primary care elderly patients: potential targets for preventive interventions. Am J Psychiatr 2009;166(12):1375-83.

30. Alvarenga MRM, Oliveira MAC, Faccenda O, Cerchiari EAN, Amendola F. Sintomas depressivos em idosos assistidos pela Estratégia Saúde da Família. Cogitare Enferm 2010;15(2):217-24. 